\title{
Impacts of Land Use and Land Cover Change on Soil Erosion and Hydrological Responses in Ethiopia
}

\author{
Ajanaw Negese $\mathbb{D}$ \\ Department of Soil and Water Resource Management, Woldia University, P.O. Box: 400, Woldia, Ethiopia \\ Correspondence should be addressed to Ajanaw Negese; ajanawnegese@gmail.com
}

Received 16 November 2020; Revised 23 January 2021; Accepted 29 January 2021; Published 16 February 2021

Academic Editor: Teodoro M. Miano

Copyright ( $\odot 2021$ Ajanaw Negese. This is an open access article distributed under the Creative Commons Attribution License, which permits unrestricted use, distribution, and reproduction in any medium, provided the original work is properly cited.

Land use and land cover (LULC) dynamics, in general, and the conversion of the natural vegetation cover into cultivated land, in particular, are major human-induced problems in Ethiopia, which have played a significant role in increasing the rate of soil erosion and altering the hydrological balance in the country. The main aim of this review was to view previous studies in Ethiopia that quantify the change in the rate of soil erosion and hydrological responses as a result of the change in land use and land cover in the country. From the past researches reviewed in this paper, the expansion of cultivated land at the expense of forest land, shrubland, and grassland in Ethiopia has increased the mean rate of soil erosion, sediment yield, surface runoff, mean wet monthly flow, and mean annual stream flow in the last four decades. On the other hand, the change has reduced the dry average monthly flow, groundwater recharge and groundwater flow, and evapotranspiration (ET) in the country. Future research works should pay more attention to the investigation of the impacts of land use and land cover change on groundwater hydrology and the prediction of future soil loss and hydrological imbalance under the changing land use and land cover in the country since little information is available from past researches on these issues. Research works are also required in lowland arid and semiarid areas in Ethiopia to effectively manage soil and water resources in all parts of the country.

\section{Introduction}

Land use and land cover (LULC) change triggered by the interaction between demographic and socioeconomic changes as well as biophysical conditions $[1,2]$ is one of the main driving forces on global and local environmental changes $[3,4]$. It exerts multidimensional consequences on essential Earth's ecosystem functions and services at local, regional, and global scales [2].

In sub-Saharan African countries, land use and land cover change, in general, and conversion of the natural land cover into agricultural land, in particular, are major continuous phenomena mainly caused by anthropogenic activities [5]. Like other sub-Saharan African countries, human-induced conversion of the natural land cover into cultivated land is the major problem in different areas of Ethiopia where agricultural activity serves as the backbone of the economy $[6,7]$.

Land use and land cover (LULC) change in Ethiopia is triggered by the interaction of various demographic, socioeconomic, institutional, and biophysical factors [1]. Studies have shown that population pressure $[6,8-11]$, widespread agricultural expansion [6,10-12], expansion of settlement $[10,12]$, rural poverty [9], inadequate management of common property resources, and land tenure insecurity due to institutional and policy reforms $[3,8,9,11,13]$ and demand for fuel wood and construction materials [10-12] were recognized as the major drivers of land use and land cover change in the country. The level of land cover conversion is particularly higher in the highland areas of the country mainly due to demographic pressures and consequent expansion of croplands and household energy demands $[6,14]$.

Different studies indicated that land use and land cover change triggered by the aforementioned factors in the country have led to severe soil erosion $[6,11,15]$, loss of biological diversity $[8,11,15,16]$, decline of agricultural production and productivity $[8,15-17]$, and decline of ecosystem service values (ESV) due to changes in individual ecosystem service functions such as erosion control, 
provision of raw material, nutrient cycling and climate regulation [18-21], and change of rural livelihood [11].

The problem of soil erosion is one of the major environmental constraints to agricultural sustainability and food security in Ethiopia particularly in the highlands [22, 23]. The overall soil loss of the country is estimated at about 1.5 billion tons per year with a mean erosion rate of $42 \mathrm{t} \cdot \mathrm{ha}^{-1} \cdot$ year $^{-1}[9,24,25]$. The rate of soil erosion has been accelerating in the country due to land use and land cover (LULC) change and inappropriate land use and management practices $[22,26]$.

The change in land use and land cover in Ethiopia also played a substantial role in changing hydrological processes such as an increase in surface runoff volumes, reduction of infiltration, and reduction of groundwater recharge in the country [27-30]. Furthermore, LULC change is one of the factors responsible for the sedimentation or siltation of lakes in the country. For instance, the extinction of Lake Alemaya in the eastern highland of Ethiopia due to siltation caused by LULC change in the upper catchment area of the lake $[31,32]$.

In recent years, the spatial and temporal change of land use and land cover (LULC) and its impacts on soil erosion and hydrological processes have gained increased attention in the country. Several previous studies [7, 23, 24, 26, 33-38] have quantified the impact of land use and land cover dynamics on soil erosion at the watershed level through the integration of revised universal soil loss equation (RUSLE) with geographic information system (GIS) and remote sensing techniques. Other research works [1, 27-30, 39-47] also investigated the impact of land use and land cover change changes on watershed hydrological processes in the country using Soil and Water Assessment Tool (SWAT), Hydrologiska Byråns Vattenbalansavdelning (HBV), and Water and Energy Transfer between Soil, Plants, and Atmosphere (WetSpa) hydrological models applied in GIS and remote sensing techniques.

As indicated in Figure 1, different studies on how LULC dynamics affect the rate of soil erosion and hydrological balance were undertaken in different areas of the country, particularly in the highlands. Despite comprehensive review and documenting of past studies on the change in soil erosion and hydrological processes due to the change in LULC is essential for future resource management, a comprehensive review of these past fragmented studies to aid future soil and water resource management is scarce in Ethiopia. Hence, the main objective of this review was to view previous studies in Ethiopia that quantify the change in the rate of soil erosion and hydrological processes as a result of the change in land use and land cover in the country.

\section{Land Use and Land Cover Change in Ethiopia}

Land use and land cover (LULC) change is the human modification of Earth's terrestrial surface from existing management of the land or land cover to new management of land or new land cover type [48]. The nature of LULC dynamics significantly differs from country to country as the drivers of LULC change and land management activities vary from place to place.

In Ethiopia, land use and land cover (LULC) change is mainly dominated by the conversion of natural vegetation cover to use for agriculture activities [9, 42]. According to FAO [49], the forest cover in Ethiopia has decreased from $13.3 \%$ of the total area of the country (14.69 million ha) in 1993 to $11.4 \%$ of the total area (12.54 million ha) in 2016 with an estimated annual rate of change $0.8 \%\left(104,600\right.$ ha $^{\prime}$ year $\left.^{-1}\right)$ (Figure 2).

On the contrary, as shown in Figure 2, the agricultural land of the country has increased from $27.66 \%$ of the total area of the country (30.54 million ha) in 1993 to $32.83 \%$ of the total area (36.26 million ha) in 2016 [49].

Several research works $[2,8,9,11,12,14,15,48,50-58]$ were undertaken on the spatial and temporal land use and land cover change at watershed and district level in Ethiopia and have shown that there has been a significant LULC change in different parts of the country dominated by the expansion of cultivated land and built-up areas at the expense of natural vegetation cover, shrublands, and grasslands particularly in the highlands.

A study by Bewket and Abebe [9] reported the consistent expansion of cropland and settlement at the expense of forest and dense tree cover over the period between 1957 and 2001 in Gish Abay Watershed, Blue Nile Basin of Ethiopia. A similar study by Hassen and Assen [13] reported that farmlands and settlement areas were expanded at the expense of forest area, shrublands, and grasslands over the study period between 1957 and 2014 in Gelda catchment, Lake Tana Watershed of Ethiopia. Tesfaye et al. [57] reported a significant increase in cultivated land and settlement and a decrease in vegetation cover between 1976 and 2008 in Gilgel Tekeze Catchment, Northern Ethiopian Highlands. According to Shawul and Chakma [56], cropland and urban area replaced a large area of forest cover and shrublands in Upper Awash Basin, Ethiopia, over the years between 1972 and 2014. Dibaba et al. [15] also found an expansion of agricultural land and built-up area at the expense of forest land in Finchaa Catchment, Northwestern Ethiopia, over the period between 1987 and 2017.

Similarly, Aneseyee et al. [18] reported the expansion of cultivated land, built-up area, and bare land at the expense of forest land and shrubland between 1988 and 2018 in Winike Watershed of Omo Gibe Basin, Southwest Ethiopia. A study conducted by Demissie et al. [51] also reported the continuous expansion of cultivated lands at the expense of forest area and grasslands over 42 years (1973-2015) in Libo Kemkem District of Northwestern Ethiopia. An increase in farmland area at the expense of forest land was also observed in Bale Mountain Eco-Region of Ethiopia from 1985 to 2015 [48]. Another study by Wubie et al. [11] found a significant increase in cultivated land and settlement and a decrease in forest land, shrubland, grassland, and wetland over 48 years (1957-2005) in Gumara Watershed of Lake Tana basin, Northwestern Ethiopia. Yesuph and Dagnew [2] reported the consistent increase in farmland and settlement area at the expense of Afro-alpine and sub-Afro-alpine vegetation areas between 1973 and 2017 in Beshillo Catchment of Blue Nile Basin, Northeastern Highlands of Ethiopia. 


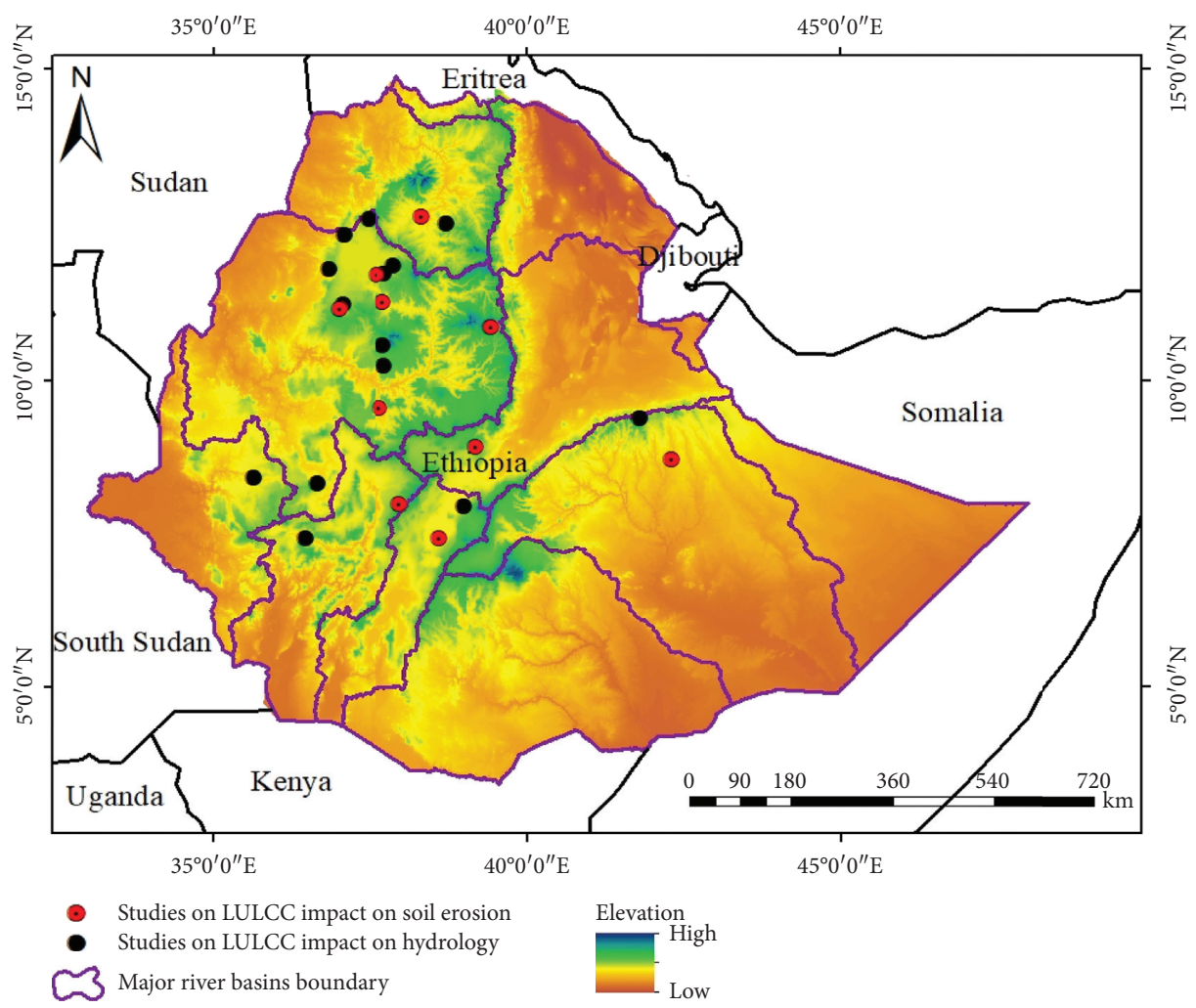

FIGURE 1: Study sites of the impact of LULC change on soil erosion and hydrological responses in Ethiopia. LULCC: land use and land cover change.

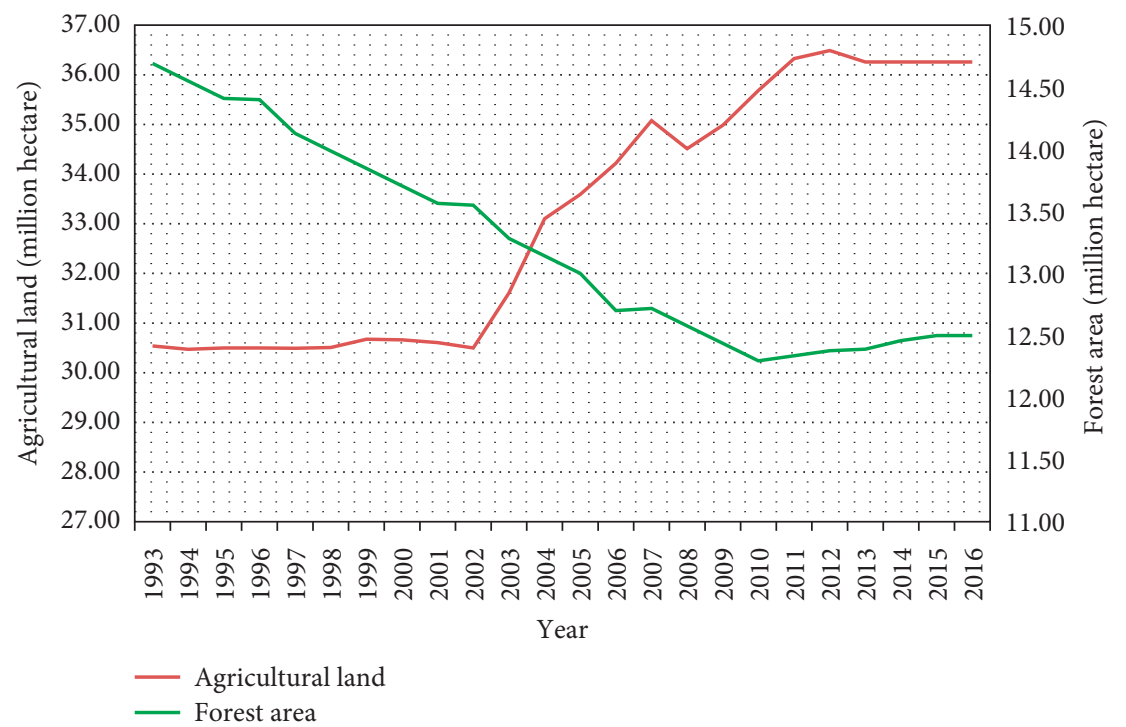

FIGURE 2: Forest cover decline and agricultural land expansion in Ethiopia between 1993 and 2016 [49].

A study conducted by Deribew and Dalacho [14] revealed that forest area was converted into agricultural land and barren land between 1957 and 2017 in the Central Highlands of Ethiopia. Ayele et al. [59] also found that farmland expansion was the major cause for the reduction of forest area between 2000 and 2015 in Delomena District, Bale Zone of Ethiopia. Belay [50] reported a significant conversion from natural vegetation cover to cropland was observed between 1957 and 1986 in Derekolli Catchment of the South Wollo Zone of Ethiopia.

The expansion of farmlands at the expense of other land use and land cover types has occurred not only in the highlands of Ethiopia but also in lowland arid and semiarid areas of the country. According to Alemu et al. [12], the expansion of agricultural land and bare land and the reduction of woodland cover were observed between 1985 and 
2010 in the Northwestern lowlands of Ethiopia. Tsegaye et al. [58] also found a rapid reduction in the size of woodland and grassland cover, and more than the eightfold increment in the size of cultivated land took place between 1972 and 2007 in arid and semiarid Northern Afar range lands of Ethiopia. Gebreslassie [60] reported cultivated lands and open lands have shown continuous expansion at the expense of forest lands, shrublands, and grasslands in Huluka Watershed, Central Rift Valley of Ethiopia, between 1973 and 2009. Cropland expanded at the expense of forest, woodlands, and grasslands between 1973 and 2014 in the Central Rift Valley of Ethiopia [8]. In the Northeastern Somali Rangelands of Ethiopia, grassland cover was converted into cultivated and settlement areas between 1985 and 2017 [61].

Contrary to the findings of the aforementioned studies in different parts of the country, Bantider et al. [62] reported the expansion of forest area and shrubland and the decline of the area of cropland since the mid-1980s in the Eastern Escarpment of Wollo, Northeastern Ethiopia. Asmamaw et al. [63] have also shown the expansion of forest land during the study period between 1958 and 2006 in Gerado Catchment of Northeastern Ethiopia.

\section{Impacts of Land Use and Land Cover Change in Ethiopia}

3.1. Impact on Soil Erosion. LULC change exerts negative impacts on ecosystem services, in general, and on biodiversity, climate, soil, water, and air, in particular [48]. Soil erosion is affected by LULC change despite other factors such as climate, soil characteristics, and topography. Land cover plays a significant role in controlling soil erosion by reducing the direct impacts of raindrops on the soil, enhancing the organic matter content in the soil, increasing the infiltration rate of water, reducing the velocity of runoff, and reducing the transportation of sediments on the surface $[64,65]$. Hence, a change in land use and land cover due to anthropogenic activities significantly affects the rate of soil erosion.

Different studies (Table 1) undertaken in different parts of Ethiopia indicated the impacts of land use and land cover change on soil erosion. Among these, a recent study made by Woldemariam and Harka [26] at Erer Subbasin, Northeast Wabi-Shebelle Basin of Ethiopia, indicated that the expansion of cropland, bare land, and settlement from $47.92 \%$, $8.03 \%$, and $0.20 \%$, respectively, in 2000 to $64.36 \%, 9.71 \%$, and $0.61 \%$, respectively, in 2018 and the decline of forestland, shrubland, and water body from $2.99 \%, 40.67 \%$, and $0.18 \%$, respectively, in 2000 to $1.42 \%, 23.87 \%$, and $0.03 \%$, respectively, in 2018 increased the mean soil loss rate of the subbasin from $75.85 \mathrm{t} \cdot \mathrm{ha}^{-1} \cdot \mathrm{year}^{-1}$ in 2000 to $107.07 \mathrm{t} \cdot \mathrm{ha}^{-1} \cdot$ year $^{-1}$ in 2018. Similarly, Kidane et al. [35] revealed that the expansion of cultivated land at the expense of forest and shrubland increased the mean rate of soil erosion from $25.8 \mathrm{t} \cdot \mathrm{ha}^{-1} \cdot$ year $^{-1}$ in 1973 to $28.7 \mathrm{t} \cdot \mathrm{ha}^{-1} \cdot$ year $^{-1}$ in 1995 and $30.3 \mathrm{t} \cdot \mathrm{ha}^{-1} \cdot$ year $^{-1}$ in 2015 and the total soil loss from 198 million t.year ${ }^{-1}$ in 1973 to 221 million t.year ${ }^{-1}$ in 1995 and 239 million t.year ${ }^{-1}$ in 2015 in Guder Subwatershed, Blue Nile basin of Ethiopia. The conversion of forest and shrubland into cultivated land in the watershed has also increased the mean sediment yield from $6.79 \mathrm{t} \cdot \mathrm{ha}^{-1} \cdot$ year $^{-1}$ in 1973 to $8.65 \mathrm{t} \cdot \mathrm{ha}^{-1} \cdot$ year $^{-1}$ and $9.44 \mathrm{t} \cdot \mathrm{ha}^{-1} \cdot$ year $^{-1}$ in 1995 and 2015, respectively [35]. Another recent study by Aneseyee et al. [66] in the Winike Watershed, Omo Gibe Basin of Ethiopia, reported that total soil loss and sediment export of the watershed increased by 176.35 and 3.85 thousand tons, respectively, over the periods between 1988 and 2018 due to the change in land use and land cover.

Another study in Andassa Watershed, Upper Blue Nile Basin of Ethiopia, revealed that the rapid expansions of cultivated land and built-up area at the expense of forest, shrubland, and grasslands for three decades (1985-2015) have increased the average soil erosion rate of the watershed

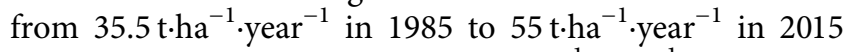
and the sediment yield from $14.8 \mathrm{t} \cdot \mathrm{ha}^{-1} \cdot$ year $^{-1}$ in 1985 to $22.1 \mathrm{t} \cdot \mathrm{ha}^{-1} \cdot$ year $^{-1}$ in 2015 [34]. Likewise, Esa et al. [33] also reported that expansion of cultivation practices has increased the mean annual soil loss rate by $16.3 \mathrm{t} \cdot \mathrm{ha}^{-1} \cdot \mathrm{year}^{-1}$, and the amount of mean sediment transported at the outlet increased by $16 \%$ between 2004 and 2014 in Gelda Catchment, Northwestern Highlands of Ethiopia. The research conducted by Tadesse et al. [23] on land use and land cover changes and soil erosion in Yezat Watershed, Northwestern Ethiopia, showed that the expansion of cultivated land and decline of sparsely wooded land, grassland, and shrubland during the period between 2001 and 2010 have increased the estimated average soil loss from $7.2 \mathrm{t} \cdot \mathrm{ha}^{-1} \cdot \mathrm{year}^{-1}$ in 2001 to $7.7 \mathrm{t} \cdot \mathrm{ha}^{-1} \cdot$ year $^{-1}$ in 2010 in the watershed. However, the implementation of integrated watershed management development programs in the watershed between 2010 and 2015 increased the extents of woodland, grassland, and homesteads by 101.69 ha $(0.67 \%), 610.69$ ha $(4 \%)$, and 126.6 ha $(0.83 \%)$, respectively, and consequently, the estimated average soil loss of the watershed decreased from $7.7 \mathrm{t} \cdot \mathrm{ha}^{-1} \cdot$ year $^{-1}$ in 2010 to $4.8 \mathrm{t} \cdot \mathrm{ha}^{-1} \cdot$ year $^{-1}$ in 2015 [23].

Another recent study by Mariye et al. [36]in Legedadi Watershed, Berhe District of Ethiopia, reported the mean annual soil loss of the watershed has increased from $54.19 \mathrm{t} \cdot \mathrm{ha}^{-1} \cdot$ year $^{-1}$ in 1997 to $66.21 \mathrm{t} \cdot \mathrm{ha}^{-1} \cdot$ year $^{-1}$ in 2013, and the maximum estimated annual soil loss of the watershed has increased from $257.1 \mathrm{t} \cdot \mathrm{ha}^{-1} \cdot \mathrm{year}^{-1}$ in 1997 to $330 \mathrm{t} \cdot \mathrm{ha}^{-1} \cdot$ year $^{-1}$ in 2013 due to the increment of cultivated land and settlement area by $18.3 \%$ and $14.34 \%$, respectively.

Similarly, a study by Moges and Bhat [37] in Rib Watershed, Northwestern Highland of Ethiopia, reported that the expansion of cultivated land at the expense of shrubland and grassland was the most detrimental factor for the increment of annual soil loss in the watershed from 0 to $236.5 \mathrm{t} \cdot \mathrm{ha}^{-1} \cdot$ year $^{-1}$ in 1986 to from 0 to $807 \mathrm{t} \cdot \mathrm{ha}^{-1} \cdot$ year $^{-1}$ in 2016 and increment of average annual soil loss of the entire watershed from $40 \mathrm{t} \cdot \mathrm{ha}^{-1} \cdot$ year $^{-1}$ in 1986 to $68 \mathrm{t} \cdot \mathrm{ha}^{-1} \cdot \mathrm{year}^{-1}$ in 
Table 1: Previous studies on LULC change impact on soil erosion in Ethiopia.

\begin{tabular}{|c|c|c|c|c|c|c|c|c|}
\hline \multirow[b]{2}{*}{$\begin{array}{l}\text { Study } \\
\text { catchments }\end{array}$} & \multirow[b]{2}{*}{ Basin } & \multirow[b]{2}{*}{$\begin{array}{l}\text { Area } \\
\left(\mathrm{km}^{2}\right)\end{array}$} & \multirow[b]{2}{*}{$\begin{array}{l}\text { Study } \\
\text { period }\end{array}$} & \multirow[b]{2}{*}{$\begin{array}{l}\text { Model } \\
\text { used }\end{array}$} & \multirow[b]{2}{*}{$\begin{array}{c}\text { Major LULC change } \\
\text { between } \\
\text { study period }\end{array}$} & \multicolumn{2}{|c|}{ LULC change impact } & \multirow[b]{2}{*}{ References } \\
\hline & & & & & & Impact indicators & $\begin{array}{c}\text { Change } \\
\text { between } \\
\text { study } \\
\text { period }\end{array}$ & \\
\hline Erer & $\begin{array}{c}\text { Wabi } \\
\text { Shebelle }\end{array}$ & 3860.00 & $2000-2018$ & RUSLE & $\begin{array}{l}\text { Cropland increased by } \\
16.44 \% \text {, and forest area } \\
\text { and shrubland decreased } \\
\text { by } 1.57 \% \text { and } 16.8 \% \text {, } \\
\text { respectively }\end{array}$ & $\begin{array}{c}\text { Mean rate } \\
\text { of soil loss } \\
\left(\mathrm{t} \cdot \mathrm{ha}^{-1} \cdot \text { year }^{-1}\right)\end{array}$ & +31.22 & $\begin{array}{l}\text { Woldemariam } \\
\text { and Harka [26] }\end{array}$ \\
\hline Guder & Blue Nile & 466.54 & 1973-2015 & RUSLE & $\begin{array}{c}\text { Forest loss by } 5.43 \% \text {; and } \\
\text { cropland increased by } \\
4.42 \%\end{array}$ & $\begin{array}{l}\text { Mean rate of soil loss } \\
\left(\mathrm{t} \cdot \mathrm{ha}^{-1} \cdot \mathrm{year}^{-1}\right) \\
\text { Total soil loss }(\mathrm{million} \\
\mathrm{t} \text { year } \\
\text { Mean Sediment yield } \\
\quad\left(\mathrm{t} \cdot \mathrm{ha}^{-1} \cdot \text { year }^{-1}\right)\end{array}$ & $\begin{array}{r}+4.5 \\
+41 \\
+2.65\end{array}$ & Kidane et al. [35] \\
\hline Andassa & Blue Nile & 587.60 & 1985-2015 & RUSLE & $\begin{array}{c}\text { Forest area decreased } \\
\text { by } 1.59 \% \text {, and } \\
\text { cropland increased } \\
\text { by } 14.11 \%\end{array}$ & $\begin{array}{c}\text { Mean rate of } \\
\text { soil loss }\left(\mathrm{t} \cdot \mathrm{ha}^{-1} \cdot \text { year }^{-1}\right) \\
\text { Mean sediment } \\
\text { yield }\left(\mathrm{t} \cdot \mathrm{ha}^{-1} \cdot \text { year }^{-1}\right)\end{array}$ & $\begin{array}{l}+19.5 \\
+7.3 \\
\end{array}$ & $\begin{array}{c}\text { Gashaw et al. } \\
{[34]}\end{array}$ \\
\hline Winike & $\begin{array}{l}\text { Omo } \\
\text { Gibe }\end{array}$ & 1091.8 & $1988-2018$ & $\begin{array}{l}\text { InVEST } \\
\text { SDR }\end{array}$ & $\begin{array}{c}\text { Forest area decreased by } \\
3.4 \% \text {, and cropland } \\
\text { increased by } 13.59 \%\end{array}$ & $\begin{array}{l}\text { Total soil loss } \\
\text { (thousand tons) } \\
\text { Sediment yield } \\
\text { (thousand tons) }\end{array}$ & $\begin{array}{r}+176.35 \\
+3.85 \\
\end{array}$ & $\begin{array}{c}\text { Aneseyee et al. } \\
{[66]}\end{array}$ \\
\hline Yezat & Blue Nile & 150.85 & $2001-2015$ & RUSLE & $\begin{array}{l}\text { Shrubland decreased by } \\
3.95 \% \text {, and cropland } \\
\text { increased by } 2.6 \%\end{array}$ & $\begin{array}{c}\text { Mean rate of soil loss } \\
\left(\mathrm{t} \cdot \mathrm{ha}^{-1} \cdot \text { year }^{-1}\right) \\
(2001-2010) \\
\text { Mean rate of soil loss } \\
\left(\mathrm{t} \cdot \mathrm{ha}^{-1} \cdot \text { year }^{-1}\right) \\
(2010-2015)\end{array}$ & $\begin{array}{l}+0.5 \\
-2.9\end{array}$ & $\begin{array}{c}\text { Tadesse et al. } \\
\text { [23] }\end{array}$ \\
\hline Legedadi & Awash & 203.18 & 1985-2013 & RUSLE & $\begin{array}{l}\text { Cropland increased by } \\
18.3 \% \text { and grazing land } \\
\text { decreased by } 25.74 \%\end{array}$ & $\begin{array}{c}\text { Mean rate of soil loss ( } \\
\left.\mathrm{ha}^{-1} \cdot \text { year }^{-1}\right) \\
\text { Maximum annual soil } \\
\text { loss }\left(\mathrm{t} \mathrm{ha}^{-1} \cdot \text { year }^{-1}\right)\end{array}$ & $\begin{array}{l}+12.02 \\
+72.9 \\
\end{array}$ & Mariye et al. [36] \\
\hline Rib & Blue Nile & 1975.00 & 1986-2016 & RUSLE & $\begin{array}{c}\text { Cropland increased by } \\
13.38 \% \text {, and shrubland } \\
\text { and grassland decreased } \\
\text { by } 5.92 \% \text { and } 6.28 \% \text {, } \\
\text { respectively }\end{array}$ & $\begin{array}{c}\text { Mean rate of soil loss } \\
\left(\mathrm{t} \cdot \mathrm{ha}^{-1} \cdot \text { year }^{-1}\right) \\
\text { Maximum annual } \\
\text { soil loss }\left(\mathrm{t} \cdot \mathrm{ha}^{-1} \cdot \text { year }^{-1}\right)\end{array}$ & $\begin{array}{r}+28 \\
+570.5\end{array}$ & $\begin{array}{c}\text { Moges and Bhat } \\
\text { [37] }\end{array}$ \\
\hline Didessa & Blue Nile & 9981.00 & 1986-2015 & SWAT & - & $\begin{array}{l}\text { Mean rate of soil loss } \\
\left(\mathrm{t} \cdot \mathrm{ha}^{-1} \cdot \mathrm{year}^{-1}\right) \\
\text { Average monthly river } \\
\text { flow }\left(\mathrm{m}^{3} / \mathrm{s}\right)\end{array}$ & $\begin{array}{l}+20.9 \\
+10.6 \\
\end{array}$ & $\begin{array}{c}\text { Chimdessa et al. } \\
{[24]}\end{array}$ \\
\hline Gelda & Blue Nile & 262.64 & 2004-2014 & RUSLE & $\begin{array}{c}\text { Farmlands increased by } \\
1.44 \% \text { and forestland } \\
\text { decreased by } 1.1 \%\end{array}$ & $\begin{array}{c}\text { Mean rate soil loss } \\
\left(\mathrm{t} \cdot \mathrm{ha}^{-1} \cdot \text { year }^{-1}\right) \\
\text { Mean sediment yield } \\
(\%)\end{array}$ & $\begin{array}{l}+16.3 \\
+16\end{array}$ & Esa et al. [33] \\
\hline
\end{tabular}

2016. A study in Didessa River Catchment, Southwest Blue Nile of Ethiopia, by Chimdessa et al. [24] has shown that the average soil loss of the river catchment increased by $9.6 \mathrm{t} \cdot \mathrm{ha}^{-1} \cdot \mathrm{yr}^{-1}, 11 \mathrm{t} \cdot \mathrm{ha}^{-1} \cdot \mathrm{yr}^{-1}$, and $20.9 \mathrm{t} \cdot \mathrm{ha}^{-1} \cdot \mathrm{yr}^{-1}$ due to LULC change between 1986 and 2000, 2001 and 2015, and 1986 and 2015, respectively.
In general, Table 1 summarizes the results of previous studies in Ethiopia which were undertaken to estimate the impacts of LULC change on the mean rate of soil loss and sediment yield in different watersheds. From the results, a significant increase in the mean rate of soil loss and sediment yield with a decreasing trend in forest cover and shrublands 
can be noticed. However, a decreasing trend in the mean rate of soil loss has been shown in Yazat Watershed of the Blue Nile basin, Northwestern Ethiopia, between 2010 and 2015 despite the decline of shrublands and expansion of cultivated lands due to the implementation of integrated watershed management development programs in the watershed.

3.2. Impact on Hydrological Responses. Watersheds hydrological processes are affected by a multitude of factors such as land use and land cover, climate, soil properties, geology of the land, and topography. Land use and land cover change mainly caused by anthropogenic interference modifies watershed hydrological processes by altering the balance between rainfall, evaporation, and runoff response of an area [24]. The change in LULC alters infiltration, groundwater recharge, surface runoff, and river flow within a watershed [45]. Therefore, a better understanding of LULC change and its effect on hydrological processes in Ethiopia is highly indispensable for the management of water resources in the country.

LULC change contributes to the change in the hydrological system in Ethiopia. Quantifying the effects of LULC change on watershed hydrological processes has recently been given much attention by the researchers, and previous studies (Table 2) in the country have quantified watershed hydrological responses as a result of the change in land use and land cover. A study in Gilgel Tekeze Catchment, Northern Highlands of Ethiopia, by Haregeweyn et al. [46] found that the increment of cultivated land by $15.4 \%$ and settlements by $9.9 \%$ at the expense of shrubland and grazing lands triggered the increment of annual surface runoff by $101 \mathrm{~mm}$, reduction of groundwater recharge by $39 \mathrm{~mm}$, and reduction of annual evapotranspiration by $91 \mathrm{~mm}$ over the period between 1976 and 2003. Similarly, Gashaw et al. [42] reported the continuous expansion of cultivated land and built-up area and diminishing of forestland, shrubland, and grassland, which have occurred from 1985 to 2015, had increased the annual flow by $2.2 \%$, wet seasonal flow by $4.6 \%$, surface runoff by $9.3 \%$, and water yield by $2.4 \%$. On the other hand, the observed changes had reduced dry season flow by $2.8 \%$, lateral flow by $5.7 \%$, groundwater flow by $7.8 \%$, and evaporation and transpiration (ET) by $0.3 \%$ in the Andassa Watershed, Blue Nile Basin of Ethiopia.

Another study by Welde and Gebremariam [30] in Tekeze Dam Watershed, Northern Ethiopia, also reported that the increment of cultivated land by $8.51 \%$ and bare land by $0.9 \%$ and the reduction of shrubland by $5.62 \%$ and grassland by $3.33 \%$ between 1986 and 2008 caused an increase of the mean annual stream flow from $129.20 \mathrm{~m}^{3} / \mathrm{s}$ in 1986 to $137.74 \mathrm{~m}^{3} / \mathrm{s}$ in 2008 and the annual sediment yield from $12.54 \mathrm{t} /$ ha in 1986 to $15.17 \mathrm{t} /$ ha in 2008 . A similar study in Gojeb Watershed, Omo-Gibe basin of Ethiopia, by Choto and Fetene [40] found that an increase of cultivated land by $14.97 \%$ at the expense of forest land and shrubland between 1985 and 2015 resulted in an increase of stream flow by $8.6 \mathrm{~m}^{3} / \mathrm{s}$ and sediment yield by 41.07 tons $/ \mathrm{km}^{2}$.
Chimdessa et al. [24] reported that land use and land cover change which occurred between 1986 and 2001, 2001 and 2015, and 1986 and 2015 have increased the average monthly river flow by $4.9 \mathrm{~m}^{3} / \mathrm{s}, 5.7 \mathrm{~m}^{3} / \mathrm{s}$, and $10.6 \mathrm{~m}^{3} / \mathrm{s}$, respectively, in Didessa River Catchment, Southwest Blue Nile Basin of Ethiopia.

Another study on the hydrological impact of land use change by Getachew and Melesse [44] in Angereb Watershed of Ethiopia reported that the mean wet monthly flow for 2011 land cover has increased by $39 \%$ compared with the 1985 land cover, and the dry average monthly flow reduced by $46 \%$ in 2011 compared with the 1985 land cover due to the expansion of cultivated land and built-up areas and decline of forest and grassland areas over the years between 1985 and 2011. Fufa et al. [41] found that the mean wet monthly flow of the catchment for 2010 land cover had increased by $3.8 \%$ compared with the 1986 land cover, and the average monthly flow in the dry season decreased by $12.3 \%$ in 2010 compared with the 1986 land cover due to the rapid expansion of agricultural land and settlement and reduction of forest land and grassland in Ketar Watershed, Lake Ziway Catchment, Ethiopia. Addisu and Tolosa [27] also reported that the increment of cultivated land from $10.8 \%$ to $39.1 \%$ and settlement area from $12.8 \%$ to $30.8 \%$ and the reduction of forest cover from $32.5 \%$ to $9.4 \%$ and grassland from $20.9 \%$ to $12.3 \%$ in Weib Catchment of Ethiopia between 1986 and 2010 caused an increase in the mean wet monthly flow for the 2010 land cover by $40.7 \%$ compared with 1986 land cover, and the dry average monthly flow for the 2010 land cover and 1995 land cover decreased by $45.2 \%$ and $26 \%$, respectively, when compared with that of 1986 land cover.

A study on the impact of land use dynamics on the base flow responses by Gessesse et al. [43] reported that the expansion of cultivated land by $29.6 \%$ and urban areas by $0.53 \%$ and reduction of shrubland by $11.9 \%$ and grassland by $18.1 \%$ caused a decrease in the base flow (the low flow) in the dry season by $0.73 \mathrm{~m}^{3} /$ year at Suha and by $0.37 \mathrm{~m}^{3} /$ year at Muga Subwatersheds between 1985 and 2015 in Choke Mountain Range of Upper Blue Nile Basin, Ethiopia.

As summarized in Table 2, the results of previous studies in Ethiopia on the impacts of LULC dynamics on watershed hydrological responses have shown a decreasing trend in the dry average monthly flow, groundwater flow and recharge, and evapotranspiration (ET) and an increasing trend in the surface runoff, mean wet monthly flow and mean annual stream flow with a considerable loss of forest cover and shrublands and expansion of cultivated lands in different watersheds. However, no significant change in hydrological components such as surface runoff, groundwater recharge, and evapotranspiration (ET) has been observed despite the significant expansion of cultivated land from $70 \%$ in 1986 to $82 \%$ in 2015 and reduction of forest land from $11 \%$ in 1986 to $5 \%$ in 2015 and grassland from $18 \%$ in 1986 to $10 \%$ in 2015 in Gumara Watershed, Blue Nile Basin of Northwestern Ethiopia [1]. 
TABLe 2: Previous studies on LULC change impact on hydrological responses in Ethiopia.

\begin{tabular}{|c|c|c|c|c|c|c|c|c|}
\hline & & & & & Major LULC & LULC chang & impact & \\
\hline catchments & Basin & $\begin{array}{l}\text { Area } \\
\left(\mathrm{km}^{2}\right)\end{array}$ & $\begin{array}{l}\text { study } \\
\text { period }\end{array}$ & $\begin{array}{l}\text { Model } \\
\text { used }\end{array}$ & $\begin{array}{c}\text { change between } \\
\text { study period }\end{array}$ & Impact indicators & $\begin{array}{c}\text { Change between } \\
\text { study period }\end{array}$ & References \\
\hline Weib & $\begin{array}{l}\text { Genale } \\
\text { Dawa }\end{array}$ & 7407.42 & $1986-2010$ & SWAT & $\begin{array}{c}\text { Forest loss by } 23.1 \% \\
\text { and crop and } \\
\text { increased by } 28.3 \%\end{array}$ & $\begin{array}{c}\text { Mean wet monthly } \\
\text { flow (\%) } \\
\text { Dry average monthly } \\
\text { flow (\%) }\end{array}$ & $\begin{array}{l}+40.7 \\
-45.2 \\
\end{array}$ & $\begin{array}{l}\text { Addisu and } \\
\text { Tolosa [27] }\end{array}$ \\
\hline Gumara & $\begin{array}{l}\text { Blue } \\
\text { Nile }\end{array}$ & 1413.00 & 1986-2015 & $\mathrm{HBV}$ & $\begin{array}{l}\text { Forest loss by } 6 \% \text {, } \\
\text { grassland decreased } \\
\text { by } 8 \% \text { and } \\
\text { cultivation } \\
\text { increased by } 12 \%\end{array}$ & $\begin{array}{c}\text { Annual river } \\
\text { discharge (mm/year) } \\
\text { Evapotranspiration } \\
(\mathrm{ET}) \\
\text { Groundwater } \\
\text { recharge } \\
\text { Surface runoff }\end{array}$ & $\begin{array}{c}\text { +300 } \\
\text { No significant } \\
\text { change } \\
\text { No significant } \\
\text { change } \\
\text { No significant } \\
\text { change }\end{array}$ & $\begin{array}{c}\text { Birhanu et al. } \\
{[1]}\end{array}$ \\
\hline Angereb & $\begin{array}{l}\text { Blue } \\
\text { Nile }\end{array}$ & 69.42 & 1985-2011 & SWAT & $\begin{array}{l}\text { Cropland increased } \\
\text { by } 7.26 \% \text {, forest loss } \\
\text { by } 2.69 \% \text {, and } \\
\text { pasture land } \\
\text { decreased by } 8.39 \%\end{array}$ & $\begin{array}{c}\text { Mean wet monthly } \\
\text { flow }(\%) \\
\text { Dry average monthly } \\
\text { flow }(\%)\end{array}$ & $\begin{array}{l}+39 \\
-46 \\
\end{array}$ & $\begin{array}{c}\text { Getachew and } \\
\text { Melesse [44] }\end{array}$ \\
\hline $\begin{array}{l}\text { Melka } \\
\text { Kuntrie }\end{array}$ & Awash & 4456.00 & $1986-2003$ & HBV & $\begin{array}{l}\text { Conversion of } \\
\text { forest, grassland, } \\
\text { and shrubland to } \\
\text { cultivated land }\end{array}$ & $\begin{array}{c}\text { Daily mean stream } \\
\text { flow }(\%)\end{array}$ & $\begin{array}{l}+2,+13,+14, \text { and } \\
+7 \text { in June, July, } \\
\text { August, and } \\
\text { September, } \\
\text { respectively }\end{array}$ & $\begin{array}{l}\text { Getahun and } \\
\text { Haj [45] }\end{array}$ \\
\hline $\begin{array}{l}\text { Tekeze Dam } \\
\text { Watershed }\end{array}$ & Tekeze & 29404.00 & $1986-2008$ & SWAT & $\begin{array}{l}\text { Cropland increased } \\
\text { by } 8.51 \% \text {, grassland } \\
\text { and shrubland } \\
\text { decreased by } 3.33 \% \text {, } \\
\text { and } 5.61 \% \text {, } \\
\text { respectively }\end{array}$ & $\begin{array}{l}\text { Mean annual stream } \\
\text { flow }\left(\mathrm{m}^{3} / \mathrm{s}\right) \\
\text { Annual sediment } \\
\text { yield }\left(\mathrm{t} \mathrm{ha}^{-1}\right)\end{array}$ & $\begin{array}{l}+8.54 \\
+2.63\end{array}$ & $\begin{array}{c}\text { Welde and } \\
\text { Gebremariam } \\
{[30]}\end{array}$ \\
\hline Gumara & $\begin{array}{l}\text { Blue } \\
\text { Nile }\end{array}$ & 1271.86 & 1973-2013 & SWAT & $\begin{array}{c}\text { Forest loss by } \\
14.38 \% \text {, cropland } \\
\text { increased by } \\
16.63 \% \text {, and } \\
\text { grassland decreased } \\
\text { by } 6.57 \% \\
\end{array}$ & $\begin{array}{l}\text { Dry season flow } \\
\left(\mathrm{m}^{3} / \mathrm{s}\right)\end{array}$ & -0.1 & $\begin{array}{l}\text { Chakilu and } \\
\text { Moges [39] }\end{array}$ \\
\hline Gojeb & $\begin{array}{l}\text { Omo } \\
\text { Gibe }\end{array}$ & 7325.67 & 1989-2013 & SWAT & $\begin{array}{c}\text { Forest loss by } \\
11.88 \% \text { and } \\
\text { cropland increased } \\
\text { by } 14.97 \%\end{array}$ & $\begin{array}{l}\text { Stream flow }\left(\mathrm{m}^{3} / \mathrm{s}\right) \\
\text { Sediment yield (tons/ } \\
\mathrm{km}^{2} \text { ) }\end{array}$ & $\begin{array}{r}+8.6 \\
+41.07\end{array}$ & $\begin{array}{l}\text { Choto and } \\
\text { Fetene [40] }\end{array}$ \\
\hline Andassa & $\begin{array}{l}\text { Blue } \\
\text { Nile }\end{array}$ & 587.60 & 1985-2015 & SWAT & $\begin{array}{l}\text { Expansion of } \\
\text { cultivated land and } \\
\text { built-up area and } \\
\text { diminishing of } \\
\text { forest, shrubland, } \\
\text { and grassland }\end{array}$ & $\begin{array}{c}\text { Annual flow (\%) } \\
\text { Wet seasonal } \\
\text { flow (\%) } \\
\text { Surface runoff (\%) } \\
\text { Water yield (\%) } \\
\text { Dry season flow (\%) } \\
\text { Lateral flow (\%) } \\
\text { Groundwater } \\
\text { flow (\%) } \\
\text { Evapotranspiration } \\
\text { (ET) }(\%)\end{array}$ & $\begin{array}{l}+2.2 \\
+4.6 \\
+9.3 \\
+2.4 \\
-2.8 \\
-5.7 \\
-7.8 \\
-0.3\end{array}$ & $\begin{array}{c}\text { Gashaw et al. } \\
{[42]}\end{array}$ \\
\hline $\begin{array}{l}\text { Gilgel } \\
\text { Tekeze }\end{array}$ & Tekeze & 352.00 & $1976-2003$ & WetSpa & $\begin{array}{c}\text { Shrubland } \\
\text { decreased by } 18.8 \% \\
\text { and cropland } \\
\text { increased by } 15.5 \%\end{array}$ & $\begin{array}{l}\text { Annual surface } \\
\text { runoff }(\mathrm{mm}) \\
\text { Groundwater } \\
\text { recharge }(\mathrm{mm}) \\
\text { Annual ET }(\mathrm{mm})\end{array}$ & $\begin{array}{l}+101 \\
-39 \\
-91 \\
\end{array}$ & $\begin{array}{l}\text { Haregeweyn } \\
\text { et al. [46] }\end{array}$ \\
\hline Ketar & $\begin{array}{c}\text { Rift } \\
\text { Valley }\end{array}$ & 3225.30 & 1986-2010 & SWAT & $\begin{array}{l}\text { Forest loss by } 53 \% \text {, } \\
\text { grassland decreased } \\
\text { by } 33.7 \% \text {, and } \\
\text { cropland increased } \\
\text { by } 27.7 \%\end{array}$ & $\begin{array}{c}\text { Mean wet monthly } \\
\text { flow (\%) } \\
\text { Dry average monthly } \\
\text { flow }\end{array}$ & $\begin{array}{l}+3.8 \\
-12.3\end{array}$ & Fufa et al. [41] \\
\hline
\end{tabular}




\section{Conclusions}

In Ethiopia, land use and land cover changes are accelerating by anthropogenic factors, and the change intern affects humans and other natural resources in general and soil and water resources in particular. Hence, the main objective of this paper was to review the impacts of land use and land cover changes on the rate of soil erosion and hydrological processes in the country.

From the past researches reviewed in this paper, the expansions of cultivated land at the expense of forest land, shrubland, and grassland in the country have increased the rate of soil erosion, sediment yield, annual surface runoff, mean wet monthly flow, mean annual stream flow, and water yield in the last four decades. On the other hand, the change has reduced the dry average monthly flow, groundwater recharge, groundwater flow, lateral flow, and evapotranspiration (ET) in the country.

From the review, it was understood that the past studies on the impacts of LULC change on hydrology did not sufficiently show the change in groundwater recharge and groundwater flow as a result of a change in LULC in the country. Hence, future research works should pay more attention to the investigation of the impacts of LUCC change on groundwater hydrology in the country.

Little information is available on the impact of land use and land cover change on soil and water resources in arid and semiarid areas of the country from past researches. Accordingly, long-term historical research on land use and land cover change and its impact on soil and water resources in lowland arid and semiarid areas of the country are required to manage the degradation of soil and water resources across all parts of the country.

From the review, it was also understood that previous studies in the country have concentrated more on the effect of past LULC change on soil erosion and hydrological processes and did not show the likely effect under the changing LULC in the future. Hence, future research works should pay more attention to forecast future soil loss and hydrological imbalance under the changing land use and land cover in the country.

\section{Data Availability}

The data used to support this review paper are from previously reported studies, which have been cited.

\section{Conflicts of Interest}

The author declares that there are no conflicts of interest.

\section{References}

[1] A. Birhanu, I. Masih, P. van der Zaag, J. Nyssen, and X. Cai, "Impacts of land use and land cover changes on hydrology of the Gumara catchment, Ethiopia," Physics and Chemistry of the Earth, Parts A/B/C, vol. 112, pp. 165-174, 2019.

[2] A. Y. Yesuph and A. B. Dagnew, "Land use/cover spatiotemporal dynamics, driving forces and implications at the Beshillo catchment of the Blue Nile Basin, North Eastern
Highlands of Ethiopia," Environmental Systems Research, vol. 8 , no. $1,2019$.

[3] E. Elias, W. Seifu, B. Tesfaye, W. Girmay, and M. Tejada Moral, "Impact of land use/cover changes on lake ecosystem of Ethiopia central rift valley," Cogent Food \& Agriculture, vol. 5, no. 1, 2019.

[4] A. C. Guzha, M. C. Rufino, S. Okoth, S. Jacobs, and R. L. B. Nóbrega, "Impacts of land use and land cover change on surface runoff, discharge and low flows: evidence from East Africa," Journal of Hydrology: Regional Studies, vol. 15, pp. 49-67, 2018.

[5] K. Näschen, B. Diekkrüger, M. Evers, B. Höllermann, S. Steinbach, and F. Thonfeld, "The impact of land use/land cover change (LULCC) on water resources in a tropical catchment in Tanzania under different climate change scenarios," Sustainability, vol. 11, no. 24, 2019.

[6] M. L. Berihun, A. Tsunekawa, N. Haregeweyn et al., "Exploring land use/land cover changes, drivers and their implications in contrasting agro-ecological environments of Ethiopia," Land Use Policy, vol. 87, 2019.

[7] G. Gebresamuel, B. R. Singh, and Ø. Dick, "Land-use changes and their impacts on soil degradation and surface runoff of two catchments of Northern Ethiopia," Acta Agriculturae Scandinavica, Section B - Plant Soil Science, vol. 60, no. 3, pp. 211-226, 2010.

[8] A. T. Ariti, J. van Vliet, and P. H. Verburg, "Land-use and land-cover changes in the Central Rift Valley of Ethiopia: assessment of perception and adaptation of stakeholders," Applied Geography, vol. 65, pp. 28-37, 2015.

[9] W. Bewket and S. Abebe, "Land-use and land-cover change and its environmental implications in a tropical highland watershed, Ethiopia," International Journal of Environmental Studies, vol. 70, no. 1, pp. 126-139, 2013.

[10] A. Fasika, T. Motuma, and T. Gizaw, "Land use land cover change trend and its drivers in somodo watershed South western, Ethiopia," African Journal of Agricultural Research, vol. 14, no. 2, pp. 102-117, 2019.

[11] M. A. Wubie, M. Assen, and M. D. Nicolau, "Patterns, causes and consequences of land use/cover dynamics in the Gumara watershed of lake Tana basin, Northwestern Ethiopia," Environmental Systems Research, vol. 5, no. 1, 2016.

[12] B. Alemu, E. Garedew, Z. Eshetu, and H. Kassa, "Land use and land cover changes and associated driving forces in north western lowlands of Ethiopia," International Research Journal of Agriculture and Soil Science, vol. 5, no. 1, pp. 28-44, 2015.

[13] E. E. Hassen and M. Assen, "Land use/cover dynamics and its drivers in Gelda catchment, Lake Tana watershed, Ethiopia," Environmental Systems Research, vol. 6, no. 1, 2017.

[14] K. T. Deribew and D. W. Dalacho, "Land use and forest cover dynamics in the North-eastern Addis Ababa, central highlands of Ethiopia," Environmental Systems Research, vol. 8, no. 1, 2019.

[15] W. T. Dibaba, T. A. Demissie, and K. Miegel, "Drivers and implications of land use/land cover dynamics in Finchaa catchment, northwestern Ethiopia," Land, vol. 9, no. 4, 2020.

[16] E. Garedew, M. Sandewall, U. Söderberg, and B. M. Campbell, "Land-use and land-cover dynamics in the central rift valley of Ethiopia," Environmental Management, vol. 44, no. 4, pp. 683-694, 2009.

[17] A.-m. A. Agidew and K. N. Singh, "The implications of land use and land cover changes for rural household food insecurity in the Northeastern highlands of Ethiopia: the case of the Teleyayen sub-watershed," Agriculture \& Food Security, vol. 6, no. 1, 2017. 
[18] A. B. Aneseyee, T. Soromessa, and E. Elias, "The effect of land use/land cover changes on ecosystem services valuation of Winike watershed, Omo Gibe Basin, Ethiopia," Human and Ecological Risk Assessment: An International Journal, vol. 26, no. 10, pp. 1-20, 2019.

[19] M. Kindu, T. Schneider, D. Teketay, and T. Knoke, "Changes of ecosystem service values in response to land use/land cover dynamics in Munessa-Shashemene landscape of the Ethiopian highlands," Science of The Total Environment, vol. 547, pp. 137-147, 2016.

[20] M. G. Markos, D. U. Mihret, E. J. Teklu, and M. G. Getachew, "Influence of land use and land cover changes on ecosystem services in the Bilate Alaba Sub-watershed, Southern Ethiopia," Journal of Ecology and The Natural Environment, vol. 10, no. 9, pp. 228-238, 2018.

[21] T. Tolessa, F. Senbeta, and M. Kidane, "The impact of land use/land cover change on ecosystem services in the central highlands of Ethiopia," Ecosystem Services, vol. 23, pp. 47-54, 2017.

[22] D. M. Moges, A. Kmoch, H. G. Bhat, and E. Uuemaa, "Future soil loss in highland Ethiopia under changing climate and land use," Regional Environmental Change, vol. 20, no. 32, 2020.

[23] L. Tadesse, K. V. Suryabhagavan, G. Sridhar, and G. Legesse, "Land use and land cover changes and soil erosion in Yezat watershed, North Western Ethiopia," International Soil and Water Conservation Research, vol. 5, no. 2, pp. 85-94, 2017.

[24] K. Chimdessa, S. Quraishi, A. Kebede, and T. Alamirew, "Effect of land use land cover and climate change on river flow and soil loss in Didessa River Basin, South West Blue Nile, Ethiopia," Hydrology, vol. 6, no. 1, 2018.

[25] H. S. Gelagay and A. S. Minale, "Soil loss estimation using GIS and remote sensing techniques: a case of Koga watershed, Northwestern Ethiopia," International Soil and Water Conservation Research, vol. 4, no. 2, pp. 126-136, 2016.

[26] G. Woldemariam and A. Harka, "Effect of land use and land cover change on soil erosion in erer sub-basin, Northeast Wabi Shebelle Basin, Ethiopia," Land, vol. 9, no. 4, 2020.

[27] T. Addisu and D. Tolosa, "Modeling change of land use on hydrological response of river by remedial measures using arc SWAT: case of Weib catchment, Ethiopia," International Journal of Innovative Technology and Exploring Engineering, vol. 8, no. 11, pp. 2381-2390, 2019.

[28] W. Bewket and G. Sterk, "Dynamics in land cover and its effect on stream flow in the Chemoga watershed, Blue Nile basin, Ethiopia," Hydrological Processes, vol. 19, no. 2, pp. 445-458, 2005.

[29] G. Tesfaye, A. Assefa, and D. Kidane, "Runoff, sediment load and land use/cover change relationship: the case of Maybar sub-watershed, South Wollo, Ethiopia," International Journal of River Basin Management, vol. 15, no. 1, pp. 89-101, 2016.

[30] K. Welde and B. Gebremariam, "Effect of land use land cover dynamics on hydrological response of watershed: case study of Tekeze Dam watershed, northern Ethiopia," International Soil and Water Conservation Research, vol. 5, no. 1, pp. 1-16, 2017.

[31] D. T. Meshesha, A. Tsunekawa, M. Tsubo, S. A. Ali, and N. Haregeweyn, "Land-use change and its socio-environmental impact in Eastern Ethiopia's highland," Regional Environmental Change, vol. 14, no. 2, pp. 757-768, 2013.

[32] S. Setegn, F. Yohannes, S. Quraishi, V. M. Chowdary, and B. C. Mal, "Impact of land use/land cover transformations on Alemaya lake, Ethiopia," Journal of Indian Water Resources Society, vol. 29, no. 3, 2009.
[33] E. Esa, M. Assen, and A. Legass, "Implications of land use/ cover dynamics on soil erosion potential of agricultural watershed, northwestern highlands of Ethiopia," Environmental Systems Research, vol. 7, no. 1, 2018.

[34] T. Gashaw, T. Tulu, M. Argaw, and A. W. Worqlul, "Modeling the impacts of land use-land cover changes on soil erosion and sediment yield in the Andassa watershed, Upper Blue Nile Basin, Ethiopia," Environmental Earth Sciences, vol. 78, no. 24, 2019.

[35] M. Kidane, A. Bezie, N. Kesete, and T. Tolessa, "The impact of land use and land cover (LULC) dynamics on soil erosion and sediment yield in Ethiopia," Heliyon, vol. 5, no. 12, Article ID e02981, 2019.

[36] M. Mariye, M. Mariyo, Y. Changming, Z. L. Teffera, and B. Weldegebrial, "Effects of land use and land cover change on soil erosion potential in Berhe district: a case study of Legedadi watershed, Ethiopia," International Journal of River Basin Management, vol. 18, pp. 1-13, 2020.

[37] D. M. Moges and H. G. Bhat, "Integration of geospatial technologies with RUSLE for analysis of land use/cover change impact on soil erosion: case study in Rib watershed, north-western highland Ethiopia," Environmental Earth Sciences, vol. 76, no. 22, 2017.

[38] A. Teshome, "Modeling the implication of land use land cover change on soil erosion by using remote sensing data and GIS based MCE techniques in the highlands of Ethiopia," International Journal of Environmental Monitoring and Analysis, vol. 6, no. 6, pp. 152-166, 2018.

[39] G. G. Chakilu and M. A. Moges, "Assessing the land use/cover dynamics and its impact on the low flow of Gumara watershed, upper Blue Nile basin, Ethiopia," Hydrology: Current Research, vol. 8, no. 1, 2017.

[40] M. Choto and A. Fetene, "Impacts of land use/land cover change on stream flow and sediment yield of Gojeb watershed, Omo-Gibe basin, Ethiopia," Remote Sensing Applications: Society and Environment, vol. 14, pp. 84-99, 2019.

[41] D. Fufa, Y. Abbulu, and G. V. R. S. Rao, "Hydrological impacts due to land-use and land-cover changes of Ketar watershed, Lake Ziway catchment, Ethiopia," International Journal of Civil Engineering and Technology (IJCIET), vol. 6, no. 10, pp. 36-45, 2015.

[42] T. Gashaw, T. Tulu, M. Argaw, and A. W. Worqlul, "Modeling the hydrological impacts of land use/land cover changes in the Andassa watershed, Blue Nile Basin, Ethiopia," Science of The Total Environment, vol. 619-620, pp. 1394-1408, 2018.

[43] A. A. Gessesse, A. M. Melesse, and A. Z. Abiy, "Land use dynamics and base and peak flow responses in the Choke mountain range, Upper Blue Nile Basin, Ethiopia," International Journal of River Basin Management, vol. 17, pp. 1-13, 2019.

[44] H. E. Getachew and A. M. Melesse, "The impact of land use change on the hydrology of the Angereb watershed, Ethiopia," International Journal of Water Sciences, vol. 1, 2012.

[45] Y. S. Getahun and V. L. Haj, "Assessing the impacts of land use-cover change on hydrology of melka Kuntrie subbasin in Ethiopia, using a conceptual hydrological model," Journal of Waste Water Treatment \& Analysis, vol. 6, no. 3, 2015.

[46] N. Haregeweyn, S. Tesfaye, A. Tsunekawa et al., "Dynamics of land use and land cover and its effects on hydrologic responses: case study of the Gilgel Tekeze catchment in the highlands of Northern Ethiopia," Environmental Monitoring and Assessment, vol. 187, no. 1, p. 4090, 2015.

[47] W. Kebede, M. Tefera, T. Habitamu, and T. Alemayehu, "Impact of land cover change on water quality and stream 
flow in lake Hawassa watershed of Ethiopia," Agricultural Sciences, vol. 5, no. 8, pp. 647-659, 2014.

[48] S. Hailemariam, T. Soromessa, and D. Teketay, "Land use and land cover change in the Bale mountain eco-region of Ethiopia during 1985 to 2015," Land, vol. 5, no. 4, 2016.

[49] FAO, "Food and Agriculture Organization Corporate Statistical Database (FAOSTAT)," 2020, http://www.fao.org/ faostat/en/\#data.

[50] T. Belay, "Land-cover/land-use changes in the Derekolli catchment of the South Welo Zone of amhara region, Ethiopia," Eastern Africa Social Science Research Review, vol. 18, no. 1, pp. 1-20, 2002.

[51] F. Demissie, K. Yeshitila, M. Kindu, and T. Schneider, "Land use/Land cover changes and their causes in Libokemkem District of South Gonder, Ethiopia," Remote Sensing Applications: Society and Environment, vol. 8, pp. 224-230, 2017.

[52] A. Fetene, T. Hilker, K. Yeshitela, R. Prasse, W. Cohen, and Z. Yang, "Detecting trends in landuse and landcover change of Nech sar National park, Ethiopia," Environmental Management, vol. 57, no. 1, pp. 137-147, 2016.

[53] D. A. Mengistu, D. K. Waktola, and M. Woldetsadik, "Detection and analysis of land-use and land-cover changes in the Midwest escarpment of the Ethiopian Rift Valley," Journal of Land Use Science, vol. 7, no. 3, pp. 239-260, 2012.

[54] T. W. Meshesha, S. K. Tripathi, and D. Khare, "Analyses of land use and land cover change dynamics using GIS and remote sensing during 1984 and 2015 in the Beressa Watershed Northern Central Highland of Ethiopia," Modeling Earth Systems and Environment, vol. 2, no. 4, pp. 1-12, 2016.

[55] A. Sewnet, "Land use/cover change at Infraz watershed by using GIS and remote sensing techniques, northwestern Ethiopia," International Journal of River Basin Management, vol. 14, no. 2, pp. 133-142, 2015.

[56] A. A. Shawul and S. Chakma, "Spatiotemporal detection of land use/land cover change in the large basin using integrated approaches of remote sensing and GIS in the Upper Awash basin, Ethiopia," Environmental Earth Sciences, vol. 78, no. 5, 2019.

[57] S. Tesfaye, E. Guyassa, A. Joseph Raj, E. Birhane, and G. T. Wondim, "Land use and land cover change, and Woody vegetation diversity in human driven landscape of Gilgel Tekeze catchment, northern Ethiopia," International Journal of Forestry Research, vol. 2014, Article ID 614249, 10 pages, 2014.

[58] D. Tsegaye, S. R. Moe, P. Vedeld, and E. Aynekulu, "Land-use/ cover dynamics in Northern Afar rangelands, Ethiopia," Agriculture, Ecosystems \& Environment, vol. 139, no. 1-2, pp. 174-180, 2010.

[59] G. Ayele, H. Hayicho, and M. Alemu, "Land use land cover change detection and deforestation modeling: in Delomena district of Bale Zone, Ethiopia," Journal of Environmental Protection, vol. 10, no. 4, pp. 532-561, 2019.

[60] H. Gebreslassie, "Land use-land cover dynamics of Huluka watershed, Central Rift valley, Ethiopia," International Soil and Water Conservation Research, vol. 2, no. 4, pp. 25-33, 2014.

[61] F. Zerfu, A. Mektel, and B. Bogale, "Land use and land cover dynamics in the North-eastern Somali rangelands of eastern Ethiopia," International Journal of Geosciences, vol. 10, no. 9, pp. 811-832, 2019.

[62] A. Bantider, H. Hurni, and G. Zeleke, "Responses of rural households to the impacts of population and land-use changes along the Eastern Escarpment of Wello, Ethiopia," Norsk
Geografisk Tidsskrift-Norwegian Journal of Geography, vol. 65, no. 1, pp. 42-53, 2011.

[63] L. B. Asmamaw, A. A. Mohammed, and T. D. Lulseged, "Land use/cover dynamics and their effects in the Gerado catchment, northeastern Ethiopia," International Journal of Environmental Studies, vol. 68, no. 6, pp. 883-900, 2011.

[64] Q. Feng, W. Zhao, J. Wang et al., "Effects of different land-use types on soil erosion under natural rainfall in the loess plateau, China," Pedosphere, vol. 26, no. 2, pp. 243-256, 2016.

[65] N. Zhang, Q. Zhang, Y. Li et al., "Effect of groundcovers on reducing soil erosion and non-point source pollution in citrus orchards on red soil under frequent heavy rainfall," Sustainability, vol. 12, no. 3, 2020.

[66] A. B. Aneseyee, E. Elias, T. Soromessa, and G. L. Feyisa, "Land use/land cover change effect on soil erosion and sediment delivery in the Winike watershed, Omo Gibe Basin, Ethiopia," Science of the Total Environment, vol. 728, Article ID 138776, 2020. 